Marquette University

e-Publications@Marquette

English Faculty Research and Publications

English, Department of

$1-1-2014$

\title{
American Readers and Their Novels
}

Amy Blair

Marquette University, amy.blair@marquette.edu

Published version. "American Readers and Their Novels," in The American Novel: 1870-1940. Eds.

Priscilla Wald and Michael A. Elliott. Oxford: Oxford University Press, 2014: 36-53. Publisher Link. (C) 2014 Oxford University Press. Used with permission. 


\title{
AMERICAN READERS AND THEIR NOVELS
}

\author{
BY AMY L. BLAIR
}

Tn 1939, Charles Lee's How to Enjoy Reading presented advice to people wishing to 1 improve their relationship to books, whether to learn how to read more profitably, or to appreciate the reading that they were already inclined to do. In a text liberally sprinkled with illustrations reminiscent of James Thurber, Lee counsels his readers that they are entitled to entertainment, and even escapism, from literature, as long as they do not wallow in "fifth-rate Cinderella distortions of actual life," and as long as their reading does not become "a perversion, a kind of ostracism, a magic carpet out of real or fancied inferiorities or defeats" (32-33). He provides a list of "What to Read," while cautioning that lists can easily become fetishized and offering blank pages for his readers to compose "My Personal Reading List." He praises the Pulitzer Prizes for the novel because "they represent a remarkably successful mingling of high-quality writing and universal appeal. [. . . It is a compliment to the American taste that thousands of readers hailed many of these books before the Pulitzer Committee selected them for awards. Here, high art and wide reader acceptance frequently meet" (IIO-II).

Lee's careful negotiation of readers' desires to be diverted by their reading and his own desire to promote "the best books" nicely encapsulates the central debates around reading that dominated the period from I870 to 1940 . Each decade of this period witnessed significant developments in both local and global environments that contributed to profound changes in the constitution of the reading public and in the contexts in which people accessed and understood their reading. During this time, literacy increased as a growing professional-managerial class began to pursue both formal and informal educational opportunities. The proliferation of libraries made books accessible even to those who could not afford to purchase them. Magazines and newspapers were more numerous, had wider circulations, and were publishing more fiction than ever thanks to the new popularity of syndicates. Labor laws resulted in increased leisure time for a large portion of the US population, and a number of leisure activities battled with reading for attention. 
At the same time, newly arrived immigrants brought to the United States cultures of reading that sometimes supplanted, and sometimes complemented or intensified, dominant cultural attitudes towards the material and social utility of reading. Newly freed slaves and other people of color, negotiating the economic and social frameworks of the rapidly industrializing United States, deployed literacy as a means of integrating in to American society and of challenging their marginalization. Women, in particular-both white women and women of color-were active in reshaping reading culture during these decades, both formally through book clubs and informally through familial and social networks.

All of these demographic and material changes led to a high-stakes debate over the very nature of reading: What kinds of books do, or should, people read, and why? Who should read? How should reading for pleasure be balanced with reading for information? What, in short, is the use of reading? And, for that matter, what are its dangers? The answers that were offered to these questions continue to drive American attitudes towards reading, literacy, and the connection of both to the duties of citizenship through the present day. Overall, the story of American readers in the decades between 1870 and 1940 is one of increased access and a growing, if somewhat grudging, acceptance of the increased pluralism of readers and reading practices.

\section{Who Read What?}

Reading practices are, of course, both highly individuated and locally influenced; the primary challenge facing historians of readership remains balancing evidence of particular readers' behaviors and the temptation to generalize from them. Still, one can discuss general trends among readers and in reported perceptions of readerly practice - the latter of which are often a complex mix of observation and attempts to direct readers' behavior. The mid-nineteenth-century United States has been considered by some the "best-educated" nation in the world at that time-_a distinction of course complicated by the stark disparity in education and literacy rates between the free and slave, or newly-freed, populations. While literacy and some experience of education were nearly universal in the free population, we know much less about the literary processes of the African American population, beyond the standard narrative of lack that accompanies the sparse evidence of technical literacy among blacks from the late nineteenth century through the beginning of the twentieth. For the most part, we can understand the spectrum of literacy at the beginning of our period as akin to Daniel and Lauren Resnick's notion of "industrial literacy," a two-tiered system "in which there is widespread rudimentary literacy across the population and a smaller elite corps of more extensively educated people with high literacy skills" (Kaestle and Radway 2009, 528). By 1940 education and literacy had expanded to the point at which high school graduation was a widely recognized rite of passage from youth to adulthood. There were many more tiers of industrial literacy by 1940, with 
all but a very few Americans completing school at least through the fourth grade. The steady increase in general literacy was influenced by, and in turn drove, the rapid spread of the periodical press from relative provincialism to national consolidation and cultural dominance by 1940 , when 80 percent of the population claimed to read newspapers on a regular basis. Although only about a quarter of the population in 1940 would report reading books regularly, the presence of serial fiction in mass periodicals meant that novels were not solely experienced by that smaller group.

In the late nineteenth century, reading was not necessarily a solitary activity. Shared story reading was a principal form of entertainment in the household. Barbara Sicherman notes the influence a culture of domestic reading bestowed on women, in particular: "As both a sanctified activity and an approved entertainment-arguably the major form of entertainment for men and women of the comfortable classes and those who aspired to join them-this reading culture had unusual power and piquancy for the women who grew up in it" (2010, 25I). The relatively well-to-do Hamilton family of Fort Wayne, Indiana, offers an example of one family's particularly intense engagement with books. The Hamiltons read to each other, cited texts as shorthand in letters to each other, memorized portions of novels and poems, and debated the boundaries of respectable fiction-"one person's trash was another's sensibility" (86-87). As in all family decisions, the issue of what to read was often contentious; Edith Abbott recalled that, growing up in the late nineteenth century, she and her siblings sometimes "rebelled when they reached their limits: the young Abbotts found the serialized stories in genteel magazines dull and implored their parents to postpone reading William Dean Howells's The Rise of Silas Lapham until they had gone to bed" ( $5 \mathrm{I}$ ). Familial reading was not practiced only by the comfortable middle class or by the native born. Rose Cohen, who emigrated from Russia with her family in the early 1890 s, came from a tradition in which her grandmother told stories while knitting; in evenings on the Lower East Side, Cohen read aloud Yiddish translations of Dickens to her rapt family audience (Sicherman 20IO, 20I-2; Cohen 1918, 187-9I). Cohen also recalls reading to her mother in English as she worked around the house; in immigrant families, where the younger members were more likely to have greater English fluency than their elders, such scenes were probably typical. Story-papers with titles such as Fireside Companion and Family Story Paper reflected and encouraged such reading among workers' families, both through their titles and through their publication schedules, timed for Sunday reading.

Groups outside the family circle also practiced communal reading. The workplace was also a site in which people read, either in groups during breaks or in idle periods, or even, as one female millworker recalled, at one's workstation from surreptitiously hidden clippings. In his fictionalized Autobiography of an Ex-Colored Man (1912), James Weldon Johnson recounts a scene in which his nameless protagonist becomes a "reader" at a cigar-wrapping factory, reminiscent of Samuel Gompers' own recollection of such activities. These, along with numerous other workers' autobiographical recollections of such practices, suggest that workplace reading was fairly common. 
The phenomenon of commuter reading in the cities likewise grew to iconic status by the 1940s; cheap "railway editions" (long in print, and now perfect for intracity commutes) made it easier for workers to read in transit to and from work, and reading advisers often encouraged their charges to take advantage of this intermediate time for a rare moment of self-care in the midst of an other-directed life. As Hamilton Wright Mabie counseled in his May 1902 column for the Ladies' Home Journal:

When you have formed the reading habit in the right way the time you spend on the street cars, in ferryboats, on journeys, in waiting for others, will constitute your chance for going to college, or of keeping up the education begun in college. Ninetenths of those who are bewailing absence of opportunity are simply blind to the opportunities which lie within their reach; for the chief difference between men does not lie in difference of opportunity but in difference of ability to recognize an opportunity when it appears.

The message of this passage is clear: the willingness and ability to seize such moments could be the difference between ultimate success or failure, not just in reading, but in life.

By 1939, Charles Lee would still emphasize the social element of reading, although with an emphasis on influencing family and friends' tastes rather than enjoying a communal experience. "You are a center of people. You become a moral and mental significance to yourself and your circle as you assimilate the best that has been thought and said in the world" (I3). Reading actually makes us "more interesting to ourselves. We become more interesting to others" (45). Books connect rather than isolate people. And when publishers began tracking the "bestselling" novels in the late nineteenth century through lists in The Bookman and Publisher's Weekly, the influence of popular taste threatened to dwarf that of professional critics. Edith Wharton worried in her 1903 essay "The Vice of Reading" about readers, particularly untrained readers, taking the reins of the marketplace; the mass reading public would, she feared, gravitate towards "the book that is being talked about, and [their] sense of its importance is in proportion to the number of editions exhausted before publication." The result of such popularity contests, she warned, was that the potential popularity of books to these philistine readers would become a more key consideration to publishers than their ethical and aesthetic duty to support "the best in literature." Wharton's concern was echoed by many literary critics in the mold of Matthew Arnold who strove to substantiate the difference between "quality" literature and "trash." As Nancy Glazener observes, in the latter part of the nineteenth century, "Books, periodicals, and their publishers became more strictly divided between those for the 'classes' and those for the 'masses,' and forums of high culture developed ever more elaborate criteria by which high and low tastes-or high tastes and low appetites, as they were usually characterized - could be discriminated" (1997, 20). Rather than grouping all novels together for condemnation, this new generation of critics carefully suggested that certain novels, but only a select few, 
could be enlivening, uplifting, and informative. The ability to differentiate grades of fiction became a marker of cultural capital for upwardly striving readers of all stripes-genteel readers who hoped to maintain a hold on their cultural dominance, middle-class readers who hoped to prove their legitimate claim to class through the performance of good taste, and lower and working class readers, new immigrants, and people of color, whose demonstration of culture became tantamount to a demonstration of fitness for citizenship and entrance into the economic system.

With so much at stake, readers gravitated to experts who would help them navigate the world of fiction, and professional critics gained notoriety even as they lamented their perceived cultural obscurity. A dizzying array of volumes with titles like Books and Reading; Or, What Books Shall I Read and How Shall I Read Them? (I88I); What I Know About Books and How to Use Them (1892); Books, Culture, and Character (1906); Open That Door! (1916); and What Books Can Do FOR YOU! (1923) offered themselves as guides for the prospective reader. Redeploying the rhetoric of upward mobility commonly associated with success manuals, the authors of reading manuals such as these increasingly counseled their audiences that all reading should redound to the intellectual, professional, and emotional benefit of the reader. By the second decade of the twentieth century, these texts came gradually to embrace readerly desires for "escape" fiction, even as they tried to raise the profile and cultural capital of "serious fiction." This gambit was strategic; after all, if the reader had become a consumer of fiction, the reading adviser's job, like any good marketer, was to simultaneously cater to and direct the consumer desire. In Middletown (1929), their longitudinal study of Muncie, Indiana, from 1890 to 1925, Robert $S$. and Helen Merrell Lynd cited a local newspaper editorial penned by a "prominent citizen" as evidence for the attractions of vicarious escape through fiction:

And so we remain at home, go to the office at eight in the morning and depart from it at six at night, and we attend committee meetings, and drive the old family bus over the streets that we have traversed a thousand times before, and in general continue the life of the so-called model citizen.

But these conditions need not fetter our fancy. In that realm we can scale the lofty Matterhorn, sail the sleepy Indian Sea, mine glittering gold in the snow-clad mountains of Alaska, tramp the Valley of the Moon, and idle along the majestic Amazon. (237-38)

These seekers after escapist fancy, not surprisingly, preferred "happy endings—or at least endings that if not exactly happy still exalt you and make you feel that the world is coming out all right" (238). The large majority of readers subscribed to periodicals that serialized such novels, and checked cheerful books out from the public library, even when cultural arbiters pressed them to leaven their more popular choices with fiction from the realist or modernist schools. Thus by 1939 , Charles Lee's ready abandonment of lists of "the classics," which perhaps serve best to "demonstrate that 'culture' existed thousands of years ago, that it is in a constant state of evolution (and 
moments of devolution-should that perhaps be spelled devilution, with a nod to the Nazis?), and that it has flourished in more golden days than these" (90-9I). The "nod" to the Nazis here signals one of the significant external influences explaining the sentiment against prescriptive lists; lists begin to smell of fascism, the dangers of which loomed large in the late 1930s. Even the bestseller lists threaten to "make Joneses of us all," and advance the trend by which "we have ceased to be self-reliant individuals" (95). By the late 1930s, it became more essential to make one's own book selections than to follow someone else's dictates, for reasons that went beyond aesthetics.

\section{Serial Fiction}

As Catherine Turner discusses in the previous chapter, the rise in cheap book production during the I870s and 188 os created new markets for fiction and dramatically increased the number of fiction titles that could be offered on a continuing basis for purchase. This availability of affordable books, combined with the presence of fiction in periodicals, provided a number of venues in which readers could experience fiction. The primary trends in periodical publication at the end of the nineteenth century were expansion, differentiation, and increasing nationalization (for an extended discussion of serialized fiction, see Chapter 18 of this volume). In 1880 , the Census Bureau's report on newspaper publication in the states and territories went it clear that local publication was the norm-newspapers were published in 2,073 of the nation's 2,605 counties. There were $97 \mathrm{I}$ daily newspapers in 1880 , with a circulation of 3.5 million in a nation of population approximately 50 million. While much of the production of papers was local, there were also growing networks among newspapers; small-town presses could purchase "readyprint" pages from major city papers that dealt with national and international news stories, and a growing telegraph network transmitted news to the hinterland. By 1882, the Associated Press consolidated its reach nationally by finally uniting the last of the regional press associations under one banner. Readyprint publishers began including fiction in their offerings with serial installments of novels in 1870 .

Charles Johanningsmeier offers an exhaustive description of the various processes by which the syndicates increased their clout with authors and publishers alike over the course of the late nineteenth century. The syndicates were profoundly significant for the dissemination of fiction. As Johanningsmeier writes, "One syndicate alone, McClure's Associated Literary Press, distributed I55 short stories and one serial novel in 1885 and II9 short stories and 16 serial novels in 1899 , each of them to an average of 20 newspapers, from Boston to San Francisco, with circulation per newspaper ranging from 10,000 to 120,000 copies" $(1997,2)$. Such numbers are impressive enough alone, but after taking into account the general rule that each copy was shared among three readers, the significance of the syndicates is even more apparent. 
Syndicates published for the most part fiction written by fairly well-known authors, but they are also considered responsible for introducing some significant authorsparticularly British authors-to American audiences for the first time. Syndicates were able to offer established writers like Henry James and William Dean Howells venues for work that they could not place elsewhere, and sometimes their pay was more lucrative than the offers that could be made by individual newspapers or by struggling genteel monthly magazines. By the end of the nineteenth century, however, the rising clout of magazines and the declining prestige of newspapers led to the decline of syndicated fiction. Serial fiction of the "better sort" became largely confined to magazines, and dedicated story-papers took over the publication of serialized dime novels. Although their heyday was relatively short-lived, the newspaper fiction syndicates must be given credit for expanding the market for serial fiction beyond genteel and middle-class readers.

When we think of serial fiction, we generally think of monthly magazines, which had been the primary locus of such activity since the eighteenth century. Many of the monthlies jockeying for readership in the I870s through I890s had begun as house organs for book publishers-the Atlantic Monthly, Harper's, Scribner's Monthly (which became the Century Magazine), Putnam's, Lippincott's, and Appleton's Journal were all monthlies that functioned to advertise their house's list, to offer previews through initial serialization, and to brand the publishing company with particular characteristics that, publishers hoped, would lead to consumer loyalty. House magazines tended to be more expensive, selling for twenty to thirty-five cents an issue on the newsstand, and targeting more affluent and culturally enfranchised readers. As extensions of book publishing operations, these magazines had an editorial stake in promoting certain works or authors as their house's distinctive "brand"; Glazener has detailed how the Atlantic group (which included Putnam's, Harper's, and others) promoted literary realism and the careers of authors such as William Dean Howells, Henry James, and Charles Chesnutt.

By the I890s, a host of new periodicals entered the scene competing for a wider, more budget-conscious audience; in 1893 a price war among $M c$ Clurés, Cosmopolitan, and Munsey's resulted in a standard baseline newsstand price of ten cents, with a dollar-a-year subscription price. The Ladies' Home Journal, which had begun as a more exclusively domestic-issues periodical, increased its general content by 1900 , when it became the first periodical to reach circulation of one million copies. Each of these general magazines relied to a great extent on the fiction they serialized each month as a continuing draw for subscribers; they offered novels as premiums for subscribing, and incorporated book chats that helped advise their more general readership on the kinds of books that would be "worth" reading, and the modes of readership that would be the most profitable. Over ten years, Hamilton Wright Mabie penned one hundred columns in the Journal that went far beyond current book recommendations, although they included plenty of them; he was just as concerned, though, with orienting his readers toward reading, helping them create a "habit of reading" 
that would allow them to embrace classic works, current elite literature, and reading for "entertainment" without prejudice or cognitive dissonance. Alongside other elite cultural arbiters, the advisers in the magazines worked to counsel readers about which books to read, and what they should be getting out of them.

Magazines also continued to serialize novels regularly, and while "elite" authors published in prestigious literary journals such as Atlantic Monthly and Harper's, and, by the I9Ios and I920s in "little magazines" such as the Dial, they could also be found in the pages of the Ladies' Home Journal, Saturday Evening Post, and Good Housekeeping. These magazines, as Christopher Wilson has pointed out, established their credentials as cultural arbiters by publishing for the most part already-established authors such as James, Howells, and Mary Wilkins Freeman, and drew readers in with more popular fare such as fiction by Kate Douglas Wiggin, Edna Ferber, and O. Henry. Wilson observes that the impulses of editors and publishers in the I9ros through I940s were to professionalize authorship that produced fictions of "middling" America - and this because such were the fictions that the vast middle of the American population would buy, and read. By the I920s, serial fiction was waning as a major form of publication for most significant authors. At most, periodicals would excerpt portions of text, or short stories, but entire novels were rarely serialized.

\section{Subscription Series}

1906 saw the first publication of books in the Everyman's Library series, which promised to make attractively bound copies of "classic literature" affordable for everyone. The sale of subscription series of books accelerated with the expansion of rural free postal delivery in 1902 . One of the most long-lived of the bounded subscription book series is the Harvard Classics "Five Foot Shelf of Books," published with inspirational synergy by P. F. Collier from I9Io through 196I. As the previous chapter observes, the Five Foot Shelf combined a reading advisor sensibility with an impressively bound edition of the works themselves. One selling point of the Five Foot Shelf was its programmatic efficiency; in just "Fifteen Minutes a Day," following the daily reading guide in a bound pamphlet with this promising title, you could learn all you needed to know to succeed socially or professionally. The advertisements for the series reinforced consumers' desires and anxieties. One ad from I92I pictures the interior of a train during the morning commute, seated men in business suits and fedoras (and one well-dressed woman), noses buried in their newspapers. (See Figure 3.I.) A lone standing passenger, eschewing the newspaper, is engrossed in a book. The banner caption crows, "Which Wins Out?" The book reader, it seems, will have a competitive business advantage over the newspaper readers because he is acquiring "'the essentials of a liberal education' - the power to think straight and talk well." A little over one month later, the reader of the Times Book Review would find a Harvard Classics ad appealing to a different set of aspirations. (See Figure 3.2.) 


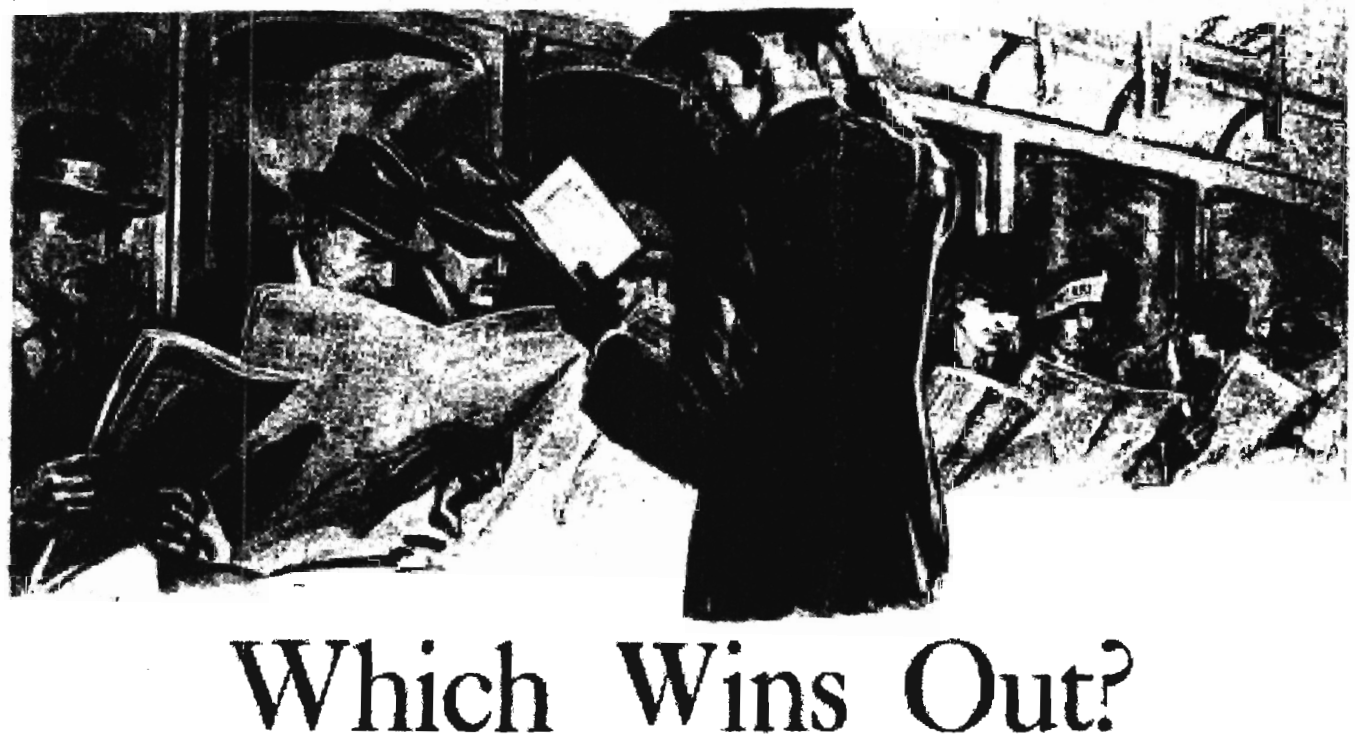

\section{Get FREE the booklet that tells what 15 minutes a day will do to make a man think straight and talk woll}

IT) Hichl wins out? The than IV apends aft his presioun reading time with the dally paper? Or the thore loreajigted one who sciese toon every spare mothent everywhere, to guin litte by little. page by page delightfully and easily that bromberes of the low truly great boaks which ean wift when to distisction and syccens. What wo the tew reat booles troctaphice, historites, novol dramus, powm, books of science and traval, philosophy and relleion - that contain mo the at a Uheral education" - the power to think otraighi and talk wetl? Dr. Churles W, Eliot, from his tifotime of readine, atody, and teach. ine. forty rears of it president of Harverd Univengity, hos anamered that question in a free booklet that you car have for the atiog. In it ate described the contente, nlan, and parpose of

\section{DR. ELIOT'S FIVE-FOOT SHELF OF BOOKS}

Every well informed man and Homan should at leost know sometrink aboot this fansons librars.

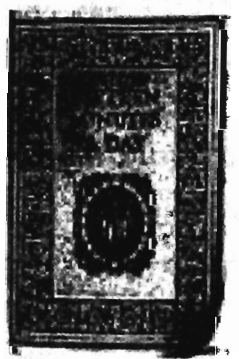

The iree book rells about it-how Dr. Eliot has put into his Five-Fon Shell "the essentisis of a liberal education," Juow the has so arranicent it that ewer "filteen minater a dag" are enough how in pleswent mo. mente of epare time, by wing the rendiang courser Dr. Hia bis proridexl for you, row can et the knowledge of liverature and life the culture, the broad viewpoint that every university utrives to give. "For ant," wrots one mant who hed went in the coupan, "your litth tree book aneant a bie kfop forward, and if whinend

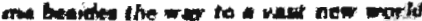
of ellowempe."

Forey reader of this page is invilud to hav a copy of this hawdrome and eateraining linle book, wieh is lree, will be cent by mail, and involves no ahtigation of and nowt. Merely clip the coopon and mail it wo-day.

\section{Send for this FREE booklet that gives Dr. Eliot's plan of reading \\ P. P. COLLIRR \& SON COMPANT

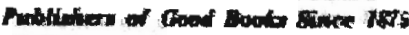

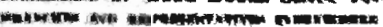

Fig 3.I "Which Wins Out?" asks this I92I advertisement for the Five Foot Shelf, a collection of books selected by Harvard President Charles W. Eliot. 


\section{Which}

\section{of these}

\section{two men}

\section{has learned}

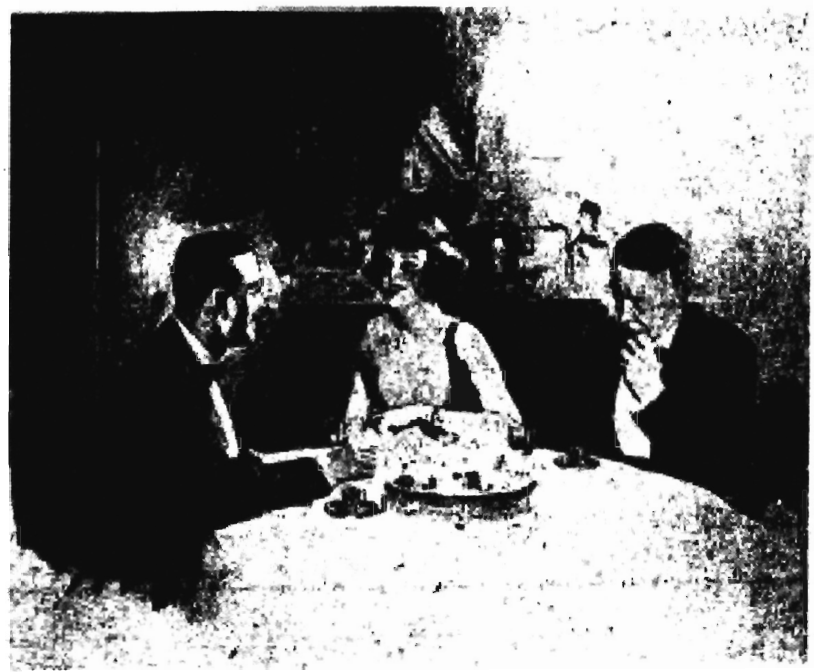

\section{the secret of 15 minutes a day?}

The sectet is cantained in the free boate offered belown. Unill you haree read it gros have no idea how much 15 minules a day can mean in grouth and success. Send for your copy nout.

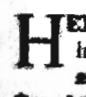

TERe are two mes, aytulty pood look.

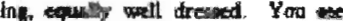
well men at every iocial potheriag

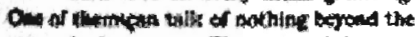
mese dry's newn The other bxinat in

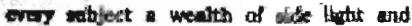

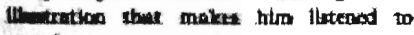
and

Fin the low a men who had traveled

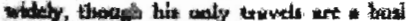

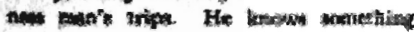
of hivtory and bioppaptry, of the work of

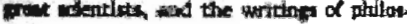

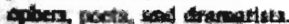

Yot be is bony, a w all met ere in the

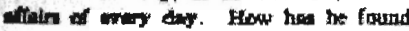

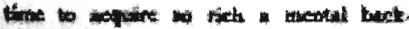

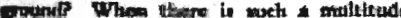

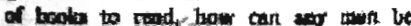
nethests

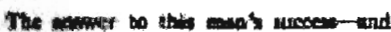

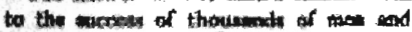

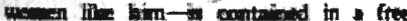

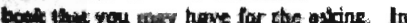

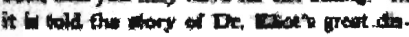

\section{Send for this FREE boodlet} that gives Dr. Bidk's owe plan of readiog

\section{P. F. COLIER EON COMPANY}

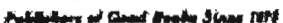

atwery, which, mas expesed it, odoes for reodions what the imention of the

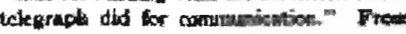

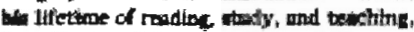
forty gram of it at Prosidest of Hermend

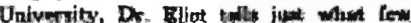

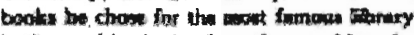
in the worldi ator be chowe them wid bew be hal arrurod then with notes and rexdine

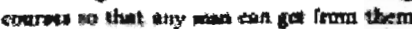

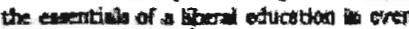

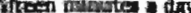

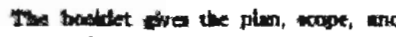
piempone of

\section{Dr. Eliot's}

Five-Foot Stelf of Books-

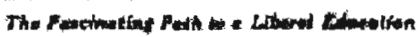

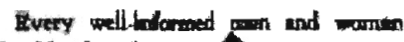

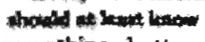
omptring abot thit ienow: liburiny.

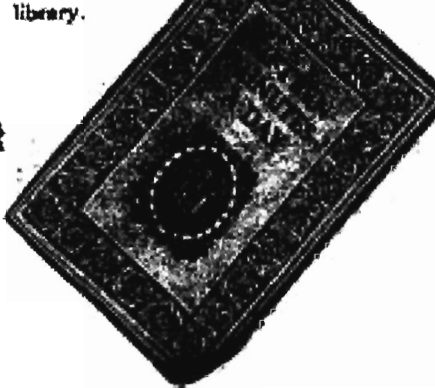

The boe bede telle about it-bew Dn.

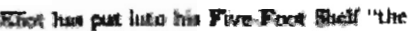

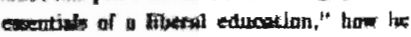

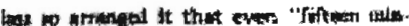
wa doy" are enowith how in plearant muments of ance time, by wing the nas-

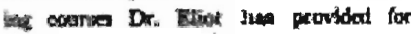

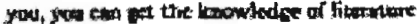
and life, the coliture, the lowd reapolat Hail ewery unimedity ofrity to ptre.

"Pix me," wroth one mar who had" cont in the coupon, "your atti fret bool andant a bie the forwand, and it

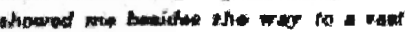
niw pariof of plowist."

Brey rouder of The How Yort t

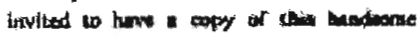

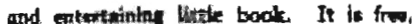

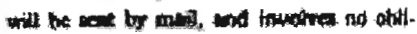

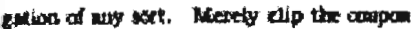
and and it bit-din.

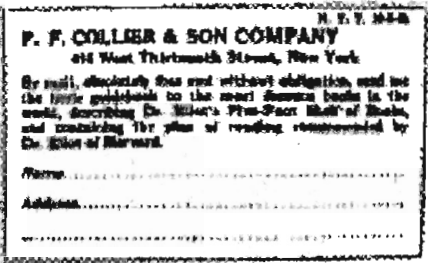

Fig 3.2 Appearing in the New York Times Book Review, this advertisement ties literary selfimprovement to masculinity. 
A lovely woman sits at a dinner table, flanked by two men in evening dress. She has turned her back on one concerned-looking gentleman while she lavishes the other (the younger and more attractive of the two) with a winning smile. The headline asks, "Which of these two men has learned the secret of 15 minutes a day?" The ad continues:

Here are two men, equally good looking, equally well dressed. You see such men at every social gathering. One of them can talk of nothing beyond the mere day's news. The other brings to every subject a wealth of side light and illustration that makes him listened to eagerly. [. . .]Yet he is busy, as all men are, in the affairs of every day. How has he found the time to acquire so rich a mental background? When there is such a multitude of books to read, how can any man be well-read?

The Five Foot Shelf is, of course, the answer to this conundrum, with its helpfully condensed and programmed plan for reading. This is "the answer to this man's success"- a success in this case not professional, but personal. By bringing a preselected slate of books right to your door, subscription series rendered the reading process more efficient; one had only to read, and the editors and publishers would perform the work of selection for you.

\section{Public Libraries}

Another cultural institution that stood at the junction of increased availability of fiction and the impulse to control reader access was the public library. In 1876 , the year that the American Library Association (ALA) was formed, the federal government published a survey that counted I88 public libraries-free municipal institutions supported by general taxation-in eleven states. While the libraries were generally concentrated in urban centers and in the east, the ALA began to push for wider library coverage across socioeconomic and rural-urban divides. As Janice Radway points out, the meeting at which the ALA was founded in 1876 was also the occasion for Melvil Dewey's public unveiling of his system for organizing library collections, a system that "was reader rather than author driven" (1997, 137). The 1876 meeting was also consumed by a debate over which novels belonged in public libraries-if they belonged there at all. "Although all conference participants agreed that dime novels like the Deadwood Dick series and tabloids like the Police Gazette had no place in a 'public' library, they disagreed on novels of 'marginal quality' like Lady Audley's Secret (1862) by Mary Elizabeth Braddon and Trial for Her Life (1869) by Mrs. E. D. E. N. Southworth" (Wiegand 2009, 431).

The question of fiction was also a question about the very purpose of a library: was it an educational institution, or an entertainment venue? The answer to that question held considerable material significance for the future of librarianship, for the prestige of the librarian, and the professional requirements of the job. The librarian 
as gatekeeper to cultural values would require credentialing and would garner professional respect; the librarian as instrumental guardian of consumer-driven collections would need fewer skills. The slight consensus reached at the 1876 convention was that "the mass reading public was generally incapable of choosing its own reading materials judiciously. Libraries should intervene for the benefit of society by acquiring and prescribing the best reading materials for the public's consumption" (Wiegand 1986, 10). Melvil Dewey's ALA motto- “The best reading for the largest number at the least expense"-left open considerable room for debate on the parameters of "best reading." These determinations, which generally excepted dime novels and story-papers but were less clear-cut in cases such as E. D. E. N. Southworth, were left up to local librarians, although the ALA would come to offer guidance by way of a number of "best reading" lists. At the 1893 convention, held at the World's Fair in Chicago, the ALA displayed a "Model Library" of five thousand of the "best books" as selected by a committee of disciplinary experts, librarians, and library school students. Only is percent of the books in this collection were fiction, despite the fact that fiction accounted for 75 percent of circulation at most public libraries (Wiegand 2009, 436-37). The public's thirst for fiction thwarted the ALA librarians' desire for professionalization, although many hoped that fiction could become a "hook" for patrons who could form a "reading habit" and move on to more elevated material. The debates were largely waged in the realm of popular novels such as Huckleberry Finn and the works of "The Duchess" (Margaret Wolfe Hungerford). There was little debate about dime novels and story-papers, objections to which, as Michael Denning and Dee Garrison have observed, were lodged on moral, not aesthetic, grounds. Since "blood and thunder" stories had been cited as pernicious influences in several murder trials, they were considered dangerous reading for the young, and there was no assurance that parents would be able to keep them out of the hands of the innocents in their homes.

Small-town librarians, who were frequently closer to their patrons than the heads of the professional organizations, tended to be more accommodating of the public's tastes. In the Sage Public Library in Osage, Iowa, the most frequent users of the library were native-born, middle-class Protestants, presumably the same group most susceptible to the encomiums about "best reading" that were published in lifestyle magazines and in newspapers. And yet, the desire for more sensational or sentimental novels, of the sort that did not make the cut into the ALA Catalog, was only slightly diluted: Bertha M. Clay, "The Dutchess," and Miss Mulock rivaled the more ALA-sanctioned William Dean Howells, Walter Scott, and Wilkie Collins for popularity among that library's patrons. By 1923, roughly half of the citizens of Muncie, Indiana, had library cards, an increase from one-fifth of the population in 1890 . Most of the books circulated from the library were fiction, although the Lynds note (with a slight note of reassurance) that, while in 190392 percent of the books taken out by adults were fiction, that number had decreased to 83 percent in 1923 . 
While libraries were public institutions, library infrastructure was largely funded through private philanthropy. Most donors gave locally, as when John Jacob Astor left $\$ 400,000$ for a library in New York City, but Andrew Carnegie’s legacy was national. Between 1880 and $1920,1,697$ Carnegie libraries were built in 1,400 communities across the United States. Carnegie's donations totaled more than $\$ 50$ million, a largesse that served as a gesture of support for the culture of self-improvement to which he attributed his own success. He stated in 1900: "I choose free libraries as the best agencies for improving the masses of the people, because they give nothing for nothing. They only help those who help themselves. They never pauperize. They reach the aspiring, and open to these the chief treasures of the world-those steeped up in books. A taste for reading drives out lower tastes" (Augst 200I, II). Mary Antin describes her young immigrant self viewing the public library as just such a refuge and an inspiration, as a "palace," but one that was built by civic funds: "Did I not say it was my palace? Mine, because I was a citizen; mine, though I was born an alien; mine, though I lived on Dover Street. My palace-mine!" (Sicherman 2010, 2II; citing Antin 1912, 34I). Immigrant children were frequently the most voracious patrons of the libraries in the major metropolitan areas, as Barbara Sicherman notes. The library offered a satisfying mix of guidance from librarians and ultimate freedom in the choice of books and in the possession of one's own library card. "In a study of twenty-six immigrant men and women educated in New York City public schools, 'Every informant spoke lovingly of books and the library, and several recounted strategies they employed to up the two-book-per-visit quota' " (Sicherman 2010, 215; citing Brumberg 1986, I4I). The pleasure of books became inextricably linked with a sense of national belonging through the use of public libraries, and prescription would ultimately not last long in the face of this heady mixture.

Not all of the potential patrons of public libraries were impressed by the civic and philanthropic largesse that hoped to direct and refine their reading; unions, community groups, and others who wanted to exert their own canons of taste inside their communities formed alternative libraries. In Alleghany, Pennsylvania, for example, workers "raised serious questions about who would control the library which Carnegie would offer the city" (Denning 1998 [1987], 50). Their skepticism was unsurprising given Carnegie's labor practices; surely it was difficult to imagine he had their best interests at heart when cornering the local market on print culture. Lacking conflict in their entertainment mission, union libraries frequently curated the kinds of collections eschewed by the public libraries: romance novels, sensation fiction, dime novels, and story-papers.

It would take a crisis requiring the entertainment of large numbers of citizens from all ranks of life to finally make the ALA similarly comfortable with the public library's hybrid function in society. The great fiction debate among librarians was resolved, for the most part, by default during the ALA campaign to provide novels to soldiers on the front during the First World War. While at home shelves were being purged of "questionable materials," such as German language texts and pacifist 
books, volunteers were donating scores of story-papers and light fiction for distribution to the military overseas. "Wartime experiences," Wiegand explains, "ultimately confirmed the American public library as a civic institution more in touch with popular reading tastes. Public library leaders finally came to accept the argument that the 'light' reading they had reluctantly provided for a half century to attract new patrons was, at worst, harmless" (2009, 448). The library, despite some of the efforts of well-meaning prescriptive librarians, had become a space for the profound democratization of reading.

\section{Study Clubs, Political Clubs}

One of the primary drivers of library patronage, according to the Lynds, was the ubiquitous ladies' civic book circle. Parodied in Sinclair Lewis's Main Street (I920) as the "Thanatopsis Club," book groups became popular social and intellectual outlets for women during the latter half of the nineteenth century. Elite white women had been meeting for book study in the United States since the early eighteenth century; such clubs were remarkable during the period between 1870 and 1940 primarily because of the increasing organization and institutionalization of the women's club movement. By 1906, five thousand clubs had joined the General Federation of Women's Clubs, and the actual number of regular meetings and study circles was clearly much higher. Barbara Sicherman and others have noted that such groups provided sympathetic companionship not always available in domestic reading settings; like-minded women could motivate each other to pursue intellectual projects that might be frowned upon at home. These clubs were also used as civic levers; women's clubs were active in voter registration drives, in movements supporting legislation significant to women, and, of course, in financing and maintaining civic literary and arts organizations. Libraries and magazines published lists of study suitable for women's clubs; many adhered to an order of business that saw one member responsible for leading discussion each week, writing a paper to present as oratory in front of the group. "Study" was a key word for women's clubs of this nature; even the fiction that came under consideration was read because of its cultural significance, and therefore the works suggested for such clubs tended not to be popular or recent offerings.

The guide to organizing a book club published in one issue of the Ladies' Home Journal in November, I897, offers a glimpse into the more genteel and social manifestations of literary clubs. The author insists, "Long biographical sketches of authors, copied from reference books, and dry, critical essays, absorbed from other writers, with little or no individual thought, should be avoided. They give a semblance of literary study without the reality." Book clubs strove to offer women entrée into the world of serious intellectual work, during a period when "education was becoming especially important for middle-class Americans, yet women maintained a tenuous 
relationship to the institutions of higher learning" (Long 2009, 478). For women who were not able to complete high school, or to attend college, the book club was a welcome channel for intellectual energy. The intricate organization of women's clubs telegraphed the gravity of the endeavor to the often skeptical, even cynical, outside world; most clubs were conducted by Robert's Rules of Order, and many dispensed entirely with refreshments so as not to seem like social, rather than business, gatherings. In the late nineteenth century, white women's clubs were frequently engaged in reform work through either charitable outreach or political action; by the mid-twentieth century, such impulses had largely retreated in the face of external resistance. There are extensive extant women's club minutes available in local archives that are just now beginning to be mined for evidence of readerly activity; the resurgence of book clubs in the late-twentieth century offers a number of compelling parallels and contrasts to the work of white women a century ago. Unfortunately, the history of white women's book groups is frequently a history of racial exclusion, thus the necessity of separate treatment of African American women's groups.

Elizabeth McHenry's work on African American literary societies has emphasized the significance of communal reading for black Americans in the nineteenth and twentieth centuries. For middle- and upper-class blacks, such societies were "places of refuge for the self-improvement of their members" as well as "acts of resistance to the hostile racial climate that made the United States an uncomfortable and unequal place for all black Americans, regardless of their social or economic condition" $(2002,17)$. African American women's clubs were at the forefront of social justice movements during the Jim Crow era at the end of the nineteenth and beginning of the twentieth centuries. A well-documented example of such engagement is the Boston club, the Woman's Era, which was formed in 1893 and which published a nationally circulating newspaper. The Women's Era newspaper became an organ for connecting women's clubs across the United States, as it published the proceedings of far-flung clubs, enabled clubs to share tips for programs of study, and advertised the charitable work being done by women in other regions. The paper was both text and forum, embodying the ways that charity work and its publications were seen as integral parts of the total project of self-advancement through reading.

In 1895 , the president of the Woman's Era called a convention in response to both a particularly vituperative attack against black woman's morality and to the exclusionary policies of many white women's clubs. This meeting, The Conference of Colored Women of America, eventually became the National Association of Colored Woman (NACW), and the Woman's Era became the group's national organ. Programs for the study of literature remained a central component of the work of NACW clubs. The newspaper often printed instructional guides and sample questions for the discussion of novels. The Era also had a literary columnist, Medora Gould, who sprinkled her text recommendations with literary gossip and encouraging words about the value of reading. While classic texts were central to this process, black women also contested the boundaries of what was considered 
"literature" by reading and promoting the work of African American and women authors. Although much of this reading, McHenry argues, "emphasized conformity to the dominant society's understanding of 'feminine sensibility' and its norms of manners and morals," this was not altogether negative, given the stereotypes against which her target audience had to signify. "A woman is most successful, Gould felt, when she transcends this conservative perspective and, through literary study, rises above the barrage of accusations of immorality and inferiority, and faces the complicated task of defining herself and her potential" (2009, 504-5). Carefully selected and conscientiously studied fiction, accompanied by judicious attention to history and biography, would achieve just such ennobling results.

The same impulses that created book clubs throughout the United States produced a club of a different kind in 1926, when Harry Scherman created the Book of the Month Club. The BOMC would act as both a filter and a procurer for the interested book purchaser who simply did not have time to do all of the careful research necessary to selecting the best books. Scherman would "manage the flood of books for his customers and thereby acclimate them to the hectic pace of modern life" (Radway 1997, 170). The BOMC recognized very explicitly the connection among reading, commerce, and culture, and proceeded from the assumption that anyone could acquire culture when given access to the right books. The BOMC's continued vibrancy through the last years of the twentieth century attests to the persistence of the ideals of reading and readership that were codified in the last half of the I80os. As the general public came to imagine themselves as readers, and began to think of reading not as an activity exclusive to the elites, but useful for the instruction and betterment of everyone, the United States became a reading nation. Despite the myriad attempts to control and constrain readers' relationships to their novels, a concern about the potential reception activities of audiences tended to steer the marketplace, and to force accommodations on the part of the cultural arbiters who wanted to determine who should read and why.

\section{Censors and Critics}

The story of censorship struggles between 1870 and 1940 offers a thumbnail sketch of changing attitudes of and toward readers during the period. In addition to the informal means of attempting to direct reader behavior I have discussed above, there was an unspoken "gentleman's agreement" among the major publishing houses not to print "obscenities" that remained largely intact through the I88os. As the publishing field opened to new companies, however, and as new philosophical and intellectual currents made their way to the United States from Europe and Asia, challenges to the genteel tradition that had not previously been able to achieve much exposure to the general public became more common. Even Hamilton Wright Mabie, in the pages of the Ladies' Home Journal, eventually came to accept some literary 
naturalism as acceptable reading; while he never conceded to Émile Zola, nor mentioned Theodore Dreiser, he did regularly recommend the gentler works of Frank Norris (The Pit [1902], if not McTeague [1899] ) to his audience. After 1900, the bohemian intellectual tradition gained traction and readership; little magazines like Little Review and Masses, and H. L. Mencken's satirical Smart Set, entered the marketplace as countervoices to the large mainstream literary journals.

People concerned about the fate of the public's morals in the face of such challenges to cultural norms found a champion in Anthony Comstock and his New York Society for the Suppression of Vice. Comstock had begun the society in 1872 , and lobbied Congress for the passage of the federal anti-obscenity laws that became known as the "Comstock Laws" in 1873 . He was appointed a federal postal inspector, a post he would hold until 1905, and was initially quite successful in prosecuting censorship claims. While most of the objectionable texts were sexually explicit drawings and photographs, Comstock targeted unexpurgated editions of Continental writers like Balzac, Tolstoy, Rabelais, and even Ovid and Boccaccio. One notable action involved the federal banning of Tolstoy's The Kreutzer Sonata, which dealt with prostitution, in 1890 .

Comstock was unable to suppress George Bernard Shaw's Mrs. Warren's Profession in New York in 1905 (it was closed in New Haven earlier that year), but his threats of prosecution prevented a British publishing house from printing Theodore Dreiser's The Genius in 1915. During the First World War, political censorship became more common after the passage of the 1917 Espionage Act and the 1918 Sedition Amendment, which targeted printed materials specifically. The Supreme Court upheld the two wartime acts in 1919, and Bolshevik and socialist movements in Eastern Europe continued to keep censors busy during the postwar years under the "clear and present danger" principle.

The I920s became a battleground for censorship on a grand scale, with Comstock's successor, John Sumner, taking on fiction in particular with renewed energy. Although he failed initially to ban Radclyffe Hall's The Well of Loneliness (1928) in New York, he successfully prosecuted Little Review for publishing sections of the Nausicäa episode of James Joyce's Ulysses in 1918. After the Little Review published an excerpt from the book that included a masturbation scene, the New York Society for the Suppression of Vice took action to have the book banned in the United States; in I92I at trial the text was declared obscene and was thereafter banned. Such successes emboldened the New England Watch and Ward Society in Boston, which, with the help of the Boston Police Department's clean books campaign, went after novels like Sinclair Lewis's Elmer Gantry (1927) and Dreiser's An American Tragedy (1925) (although the prosecution for the latter did not "stick"), alongside less-burnished titles like Elinor Glyn's Three Weeks (1907) and Floyd Dell's Janet March (1923). Although roundly criticized by the intellectual establishment, and by many publishers, the Watch and Ward and the police had the support of many nonacademic Bostonians. In 1929, the Watch and Ward successfully brought a case 
to the Massachusetts court that resulted in D. H. Lawrence's Lady Chatterley's Lover (1928) being declared obscene; objections to this ruling resulted in a liberalization of the Massachusetts obscenity statute in 1930, though it would take thirty more years for Lady Chatterley to be available in the United States.

The trend of legislative relaxation of censorship laws continued on the national level in the 1930s, when the Smoot-Hawley tariff included a provision for judicial review of all prior censorship rulings by the Customs Bureau in which works of "literary or scientific merit" could be returned to circulation. This set up the 1933 U.S. District case United States v. One Book Called "Ulysses." In a decision that termed the novel an "astonishing success" on formal and aesthetic grounds, Justice John Woolsey roundly rejected the Hicklin rule, which had been the prior standard for determining obscenity. The Hicklin rule had held that the work's effect on the most susceptible members of society should determine its evaluation; Woolsey countered that the effect on the average reader should be the determining factor. Where the Hicklin rule allowed for books to be judged based on isolated passages, Woolsey maintained that the work needed to be judged as a whole. Woolsey's reader response-centered decision concludes that the novel's overall impact is not prurient: "I am quite aware that owing to some of its scenes 'Ulysses' is a rather strong draught to ask some sensitive, though normal, persons to take. But my considered opinion, after long reflection, is that whilst in many places the effect of 'Ulysses' on the reader undoubtedly is somewhat emetic, nowhere does it tend to be an aphrodisiac. 'Ulysses' may, therefore, be admitted into the United States."

The significance of these censorship battles to the reader between 1870 and 1940 goes beyond the question of whether readers would have access to books, although that surely was one of the important considerations. Behind the shifting attitudes towards censorship were also shifting attitudes towards the "average reader's" ability to comprehend, evaluate, and interpret literature for her- or himself. Woolsey's decision, affirming as it did the average reader's sensibility, was likewise a reflection of a public becoming more accepting of the multiplicity of voices that comprised the national, and international, discourse. 